\title{
Views of primary Thai teachers toward STREAM education
}

\author{
Prasart Nuangchalerm ${ }^{1}$, Veena Prachagool ${ }^{2}$, Treekom Prommaboon ${ }^{3}$, Juhji Juhji ${ }^{4}$, Imroatun \\ Imroatun $^{5}$, Khaeroni Khaeroni ${ }^{6}$ \\ ${ }^{1,2}$ Faculty of Education, Mahasarakham University, Thailand \\ ${ }^{3}$ Faculty of Education, Rajabhat Surindra University, Thailand \\ ${ }^{4,5,6}$ Faculty of Education and Teacher Training, Universitas Islam Negeri Sultan Maulana Hasanuddin Banten, Indonesia
}

\begin{tabular}{l}
\hline Article Info \\
\hline Article history: \\
Received Mar 18, 2020 \\
Revised Sep 28, 2020 \\
Accepted Oct 29, 2020 \\
\hline
\end{tabular}

\section{Keywords:}

In-service teacher Integrated learning Small book STREAM education Teachers' views

\begin{abstract}
This study employed survey method for exploring views of teachers toward science, technology, reading, engineering, arts and math science, technology, reading, engineering, arts and math (STREAM) education. Primary teachers were asked their views through questionnaires after STREAM education workshop. Results revealed that teachers have holistic view and having positive view towards STREAM education even though all of them are not science or mathematics teachers. Change in belief and way of practices can allow teachers to do STREAM education in every classroom, design-based learning and creative classroom should be promoted as well. However, holistic view will be more effective into classroom, technology and other supporting learning environments should be prepared.
\end{abstract}

This is an open access article under the CC BY-SA license.

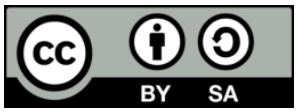

Corresponding Author:

Prasart Nuangchalerm,

Faculty of Education,

Mahasarakham University,

Muang Mahasarakham 44000, Thailand.

E-mail: prasart.n@msu.ac.th

\section{INTRODUCTION}

Science, technology, reading, engineering, arts and math science, technology, reading, engineering, arts and math (STREAM) education is an integrated approach to worldwide education, it needs to invite to curriculum and school activities. Teachers have to aware in what they teach students, based on creatively practices about science, technology, engineering, and mathematics. But the new approach need to expand concept of STEM to STEAM education where reported in Korea [1-9]. The new paradigms of teaching and new learning environments in reforming era calls for students-centered approach, is well-designed classroom. The concept of integration or holistic view seems to be best for contemporary education [10]. Art and other related disciplines can be embedded to integrated approach to different classroom contexts. STREAM education consisted of science, technology, reading, engineering, arts, and mathematics disciplines. It is employed to this study based on the critical education in reading competency which is not satisfied to Thai community.

Thailand has now been launched national curriculum standard in 1999, the curriculum purposes students to have knowledge in the relation to modern life, students can live with others, having life long learning behavior, and live with nature in balance. Curriculum needs students to have effectively learning, they should be known and must be done. Curriculum guides contents and ways of thinking for classroom design, teachers can employ different methods of teaching based on school context. But teachers tended to focus on knowledge acquisition through direct instruction, teachers may have connecting relevant 
disciplines [11]. The concept is distributed to various kinds of school management and teachers' practice. But the result of international assessment such as TIMSS and PISA, also O-NET and other testing indicated that Thailand needs to improve students' learning quality through alternative and effective education practices [12-14].

Teachers can increase students' learning competency through various kinds of methods, teaching through integration, school integrated learning, professional learning community, enhancing 21 st century learning skills and so on. Teachers are key important factor to shape quality of education, teachers act as change agent to students' effective learning [15]. Holistic education is alternative approach which distributing to education worldwide. The world is now uncertainty which influenced through different political, economical, social, and technological factors. The key success of students had the source of learning competence, quality of students come from quality of teachers. That is, teacher should adapt and adopt teaching strategies to fit with the era of social change [16, 17]. Real life situation of students cannot be separated from the truth of integration, but educational system and existentialists make students far from the purposes of changing world.

The study adopted STEM/STEAM education to be STREAM education by aiming primary teachers who joined development program, the program for enhancing teachers' competency in curriculum and learning management for Thai teachers. The program purposes to help primary students in learning achievement, analytical thinking, and writing. STREAM education, teachers have abilities and competencies to build creative citizens for the future. Reliable knowledge and process of science can promote student do and think same as scientists, but tomorrow, our society need less existing conservative knowledge, innovation and problem solving make our children to face with uncertainty world. STREAM education as words in this project set for building in-service teachers to initiate their curriculum and instruction based on integrated learning. The study examines workshop to help teachers understand STREAM education and also teachers' views toward learning management by STREAM education is studied.

\section{RESEARCH METHOD}

\subsection{Participants}

The surveying method was employed for gathering views of primary teachers towards STREAM education. The participants were volunteering primary Thai teachers who joined development program, the program for enhancing teachers' competency in curriculum and learning management for Thai teachers based on STREAM education. The program purposes to help primary students in learning achievement, analytical thinking, and writing. Seventeen teachers who have been teaching in primary schools' level from Surin province, Thailand. Participants are primary teachers are mostly female, a young blood teachers 20-30 years, and having teaching experiences between 0 and 5 years as shown in Table 1. They are the most of new generation of primary teachers, ready to learn new things, concerning integration practices as well as educational policy.

Table 1. Demographic information of participants

\begin{tabular}{cccc}
\hline & Information & Frequency & $\%$ \\
\hline \multirow{2}{*}{ Sex } & Male & 2 & 11.76 \\
& Female & 15 & 88.24 \\
20-30 years & 10 & 58.82 \\
Age & 31-40 years & 3 & 17.65 \\
& 41-50 years & 1 & 5.88 \\
& More than 50 years & 3 & 17.65 \\
Teaching experiences & 0-5 years & 11 & 64.71 \\
& 6-10 years & 2 & 11.76 \\
& 11-15 years & 1 & 5.88 \\
& 16-20 years & - & - \\
& More than 20 years & 3 & 17.65 \\
\hline
\end{tabular}

Teachers in this study are mostly constructive and productive generation. Female with teaching experiences less than five years. All of them have not been known and join any workshop about STEM or STREAM education in earlier. It is very surprisingly reported that they did not know the concept of integration by STEM or STREAM education in their curriculum development and classroom management. When they hear about STEM education, it means that science, mathematics and computer teachers are closely concerned than those any subject teachers for its implementation. 


\subsection{Research instrument}

Questionnaire about views of teachers toward STREAM education is employed. The 5-rating scale is made for gathering teachers' understanding in freely items, the questionnaire is adapted for seeking teachers' views on integration teaching from Nuangchalerm [13]. Demographic information asked sex, age, educational background, and STREAM education understanding were set. Items are dependently answered by 20 items by teachers through Google form. Qualitative data from interviewing is collected through the workshop, how teachers express their view into STREAM education. Self-reflection during workshop also gathered at the final section of workshop.

\subsection{Data collection}

Data were collected in the workshop on STREAM education for primary teachers in Surin province, held on 2-day period in February 2020. All participants completed the questionnaire, recheck the completion of form. The researcher was in the workshop room during they response to the items. Then, the data were obtained and recheck the completeness. Data were analyzed in terms of percentage, mean, and standard deviation. The interviewing can be presented in teachers' views toward STREAM education and learning dialogues.

\subsection{Data analysis}

Data were analyzed by descriptive statistics, mean and standard deviation. Views of primary Thai teachers toward STREAM education can be calculated and interpreted by indicating into 5 levels of mean for interpreting: highest (4.51-5.00), high (3.51-4.50), medium (2.51-3.50), low (1.51-2.50), and lowest (1.001.50). Its interpretation is represented by level of views and descriptive information which can be shown in the details of mean, level of views in each item.

\section{RESULTS}

If we recognize STREAM education, we will refer to science, technology, reading, art, and mathematics disciplines. Participants cannot imagine how to adopt it into Thai language teaching. The workshop creates small book activity to let them know and understand integrating approach with 5 steps. The small book activity tries to make them design in both process and product that science, technology, reading, engineering, and mathematics. Then they were asked views towards STREAM education by freely responding. The views of primary teachers toward STREAM education can be shown in Table 2.

Table 2. Views of primary Thai teachers on STREAM education

\begin{tabular}{|c|c|c|c|}
\hline Item & Mean & SD & Level of views \\
\hline $\begin{array}{l}\text { STREAM education is an integrated learning, concerning in S-science; T-technology; } \\
\text { R-Reading; E-engineering; A-Art, and M-mathematics only }\end{array}$ & 3.71 & 0.85 & High \\
\hline STREAM education is very complicated for instructional practices & 3.29 & 0.69 & Medium \\
\hline STREAM education employs project-based learning & 3.53 & 0.72 & High \\
\hline $\begin{array}{l}\text { Objectives of STREAM education want to enhance students' necessary learning skills } \\
\text { in the } 21^{\text {st }} \text { century }\end{array}$ & 4.24 & 0.90 & High \\
\hline $\begin{array}{l}\text { Objectives of STREAM education need students meet the requirement of basic } \\
\text { education curriculum }\end{array}$ & 3.65 & 0.79 & High \\
\hline Objectives of STREAM education need students able to analyze and solve problem & 4.29 & 0.77 & High \\
\hline Objectives of STREAM education engage students to have active learning & 3.82 & 0.88 & High \\
\hline STREAM education should be conducted in only science or mathematics subjects & 2.29 & 1.05 & Low \\
\hline $\begin{array}{l}\text { STREAM education should be manipulated in moderate class, more knowledge } \\
\text { program }\end{array}$ & 2.71 & 1.21 & Medium \\
\hline $\begin{array}{l}\text { Teachers pay their attention less in teach, STREAM classroom just assign work to } \\
\text { students }\end{array}$ & 3.00 & 1.06 & Medium \\
\hline STREAM education, students have to show their worksheet or production & 3.41 & 0.80 & Medium \\
\hline Team-based teaching requires for STREAM education classroom & 3.47 & 0.94 & Medium \\
\hline STREAM education must be facilitated students to concentrating in project materials & 3.00 & 1.06 & Medium \\
\hline STREAM education is less questioning, but action learning is very important to students & 3.47 & 1.28 & Medium \\
\hline STREAM education classroom requires ICT and internet resources & 3.59 & 0.80 & High \\
\hline STREAM education employs portfolios as a vital tool for learning assessment & 3.53 & 1.01 & High \\
\hline STREAM education focuses on subject matters and learning achievement in the lesson & 3.29 & 0.85 & Medium \\
\hline $\begin{array}{l}\text { STREAM education must be assessed students' progress in both process and product of } \\
\text { learning }\end{array}$ & 3.65 & 0.79 & High \\
\hline STREAM education can be considered learning behavior through learning activities & 3.88 & 0.93 & High \\
\hline STREAM education ignores contents which appear and determine in core curriculum & 3.24 & 0.97 & Medium \\
\hline
\end{tabular}


Teachers express their views in different levels between low and high. STREAM education should be conducted in only science or mathematics subjects is at low level, that is, teachers showed holistic view towards STREAM education. It cannot conduct only in specific subjects in science and mathematics. That is a holistic view which teacher perceived by means of less reductionist view. However, school contexts may be different in admistrational policy and readiness of facilities supporting teachers and students. Their views showed a positive thinking and tend to be implementing integrated learning in such practical ways.

In response to views toward STREAM education of teachers, the high level of views can be showed in several items. Objectives of STREAM education need students able to analyze and solve problem, Objectives of STREAM education want to enhance students' necessary learning skills in the 21 st century, STREAM education can be considered learning behavior through learning activities, Objectives of STREAM education engage students to have active learning, STREAM education is an integrated learning, concerning in S-science; T-technology; R-Reading; E-engineering; A-Art, and M-mathematics only, Objectives of STREAM education need students meet the requirement of basic education curriculum, STREAM education must be assessed students' progress in both process and product of learning, STREAM education classroom requires ICT and internet resources, STREAM education employs project-based learning, and STREAM education employs portfolios as a vital tool for learning assessment as it in following.

While the medium level of teachers' views can be reported that they response to STREAM education as team-based teaching requires for STREAM education classroom, STREAM education is less questioning, but action learning is very important to students, STREAM education, students have to show their worksheet or production, STREAM education is very complicated for instructional practices, STREAM education focuses on subject matters and learning achievement in the lesson, STREAM education ignores contents which appear and determine in core curriculum, Teachers pay their attention less in teach, STREAM classroom just assign work to students, STREAM education must be facilitated students to concentrating in project materials, and STREAM education should be manipulated in moderate class, more knowledge program as it in following.

The empirical reflection of teachers after they joined the workshop, positive reflection based on never knowing about STEM or STREAM education for Thai language teaching. Concept in what they know and how they do by employing STREAM education into curriculum practices:

"STREAM education can be applied into language teaching, I am firstly thought that only science and mathematics teachers can do, but now Thai teachers can manipulate STREAM education classroom" (Teacher A)

"STREAM education is an integrating discipline, students can enhance their competency in reading, analytical thinking, and writing as well" (Teacher $\mathrm{A}$ )

"STREAM education helps me to understand in integration, teachers can take multidisciplinary approach to classroom. Teachers also comprehend about objectives, assessment, and teaching activities which allow students to work with assignment in creatively" (Teacher B)

"STREAM education allows students to collaborate and concentrate with their work, solve the daily life problem, create in what they know and learn from others" (Teacher C)

"STREAM education starts with curriculum analysis; teachers have to know and design their classroom activities based on learning standards" (Teacher D)

“Creativity is very important to students' learning. Teachers have to stimulate students think and do in freely, they can make trial-error learning, but it is valuable experiences to produce new knowledge, and also conclude in what they did by the best" (Teacher D)

Participants can apply STREAM education into school curriculum and teaching strategies, it can engage students to learn and do with problem that solvable by employing necessary learning skills. They have views between survey and interview with concurrence responses. STREAM education should be invited and corporate into classroom as well as making their students having necessary learning skills. Also, students can bring integrated approach to solve problem in daily lives with creatively designed. Teachers have more understanding and making mindset to employed STREAM education into their classroom through designedbased learning. 


\section{DISCUSSION}

Views of teachers toward STREAM education with small book activity is an example to them by conducting design-based learning. Findings showed that they have different views and reflection showed that STREAM education van be acceptable into their classroom. They can get scientific knowledge through reliable multi-media as source of science. Then, they think, they do with the creativity as well as other disciplines allowed. Teachers perceived that STREAM education is difficult to mix it up between disciplines, from interdisciplinary to multidisciplinary. It helps students able to analyze and solve problem through integration, enhance students' necessary learning skills in the 21 st century as well as knowledge use based on theoretical backup $[5,8,9,13]$. In addition, STREAM education let students learn in what they preferred as well as creativity needed. They can use creative problem-solving through language teaching i.e. reading, writing, speaking and also listening with peer collaboration. However, scientific contents must be contemporary to their life. Teachers should act as mastery learner, seeking reliable knowledge to language class. Students could be integrated learning in several disciplines S-science; T-technology; R-Reading; Eengineering; A-Art, and M-mathematics. It may be than those previous disciplines because real life situation, we cannot separate alone discipline to solve the problem [17].

Teachers can simply start with integration by analyzing students' learning behaviors, curriculum, instruction, and assessment which appropriate in different classroom. Especially, teachers have to changed mindset to classroom; learning assessment should be measured in both process and product of learning $[14,18]$. Teachers should allow students to have scientific knowledge and use multi-practices for making connection among necessary skills, thinking, and attributes through designed-based learning [19-21]. Teachers have more understanding and belief that STREAM education is not difficult to invite to classroom, the positive views of teachers toward STREAM education can be reported [3, 22, 23]. However, the program for teacher development should have subsidize by government or Ministry of Education to make strong belief to teachers. Teachers can do integration and make classroom with innovative learning as well as STREAM education plays it role to new normal classroom. It helps teachers and students design on what we have to think and learn based on creative problem solving [24].

The learning environment should be supported by leading technology into every school, teachers can success STREAM education based on teaching commitment, "I can do it" leads teachers manipulate classroom to new environment. It is not just only instructional practices; teachers also know and understand how to assess students' learning by various kinds of methods and tools for assessment $[10,11,25]$. Teachers employ design-based learning, student use creative-based learning where the STREAM education meets the requirement of integrated learning as well. Teachers should change their role to be lesson designer and authentic assessor, also facilitator to engage students meet their learning abilities [26]. It will be sustainable education, if teachers ready to change their mindset and teaching role by non-focused theory. Classroom environments should challenge students in the way of creatively learning and solvable problem classroom through integration [27], and teachers have to pay their lesson design by incorporating pedagogy to fit with content or pedagogical content knowledge [28-30]. However, technology may be referred to communication and tools for creating which need to be discussed by different school practices.

\section{CONCLUSION}

Teachers have holistic view in terms STREAM education, small book activity is an example to let them know how to design and integrate disciplines into classroom. Teachers have positive views toward STREAM education even though all of them are not science or mathematics teachers. That is, they are ready to be lesson designer and learning assessor. However, holistic view will be more effective into classroom, technology and other supporting learning environments should be prepared as well as educational policy, financial subsiding, sustainable and continuing education policy, and curriculum development in both teachers and students.

\section{REFERENCES}

[1] Shin, Y. J. and Han, S. K., "A study of the elementary school teachers' perception in STEAM (Science, Technology, Engineering, Arts, Mathematics) education," Journal of Korean Elementary Science Education, vol. 30, no. 4, pp. 514-523, 2011.

[2] Kim, S. W., Chung, Y. L., Woo, A. J. and Lee, H. J., "Development of a theoretical model for STEAM education," Journal of the Korean Association for Science Education, vol. 32, no. 2, pp. 388-401, 2012.

[3] Yakman, G. and Lee, H., "Exploring the exemplary STEAM education in the US as a practical educational framework for Korea," Journal of the Korean Association for Science Education, vol. 32, no. 6, pp. 1072-1086, 2012. 
[4] Lee, J. W., Park, H. J. and Kim, J. B., "Primary teachers' perception analysis on development and application of STEAM education program," Journal of Korean Elementary Science Education, vol. 32, no. 1, pp. 47-59, 2013.

[5] Guyotte, K. W., Sochacka, N. W., Costantino, T. E., Walther, J. and Kellam, N. N., "STEAM as social practice: Cultivating creativity in transdisciplinary spaces," Art Education, vol. 67, no. 6, pp. 12-19, 2014.

[6] Kim, D. H., Ko, D. G., Han, M. J. and Hong, S. H., "The effects of science lessons applying STEAM education program on the creativity and interest levels of elementary students," Journal of the Korean Association for Science Education, vol. 34, no. 1, pp 43-54, 2014.

[7] Lim, S. M., Kim, Y. and Lee, T. S., "Analysis of elementary school teachers' perception on field application of STEAM education,” Journal of Science Education, vol. 38, no. 1, pp. 133-143, 2014.

[8] Sim, J. Lee, Y. and Kim, H. K., "Understanding STEM, STEAM education, and addressing the issues facing STEAM in the Korean context," Journal of the Korean Association for Science Education, vol. 35, no. 4, pp. 709-723, 2015.

[9] Liao, C., "From interdisciplinary to transdisciplinary: An arts-integrated approach to STEAM education," Art Education, vol. 69, no. 6, pp. 44-49, 2016.

[10] Kang, N. H., "A review of the effect of integrated STEM or STEAM (science, technology, engineering, arts, and mathematics) education in South Korea," Asia-Pacific Science Education, vol. 5, no. 1, pp. 1-22, 2019.

[11] Brundrett, M. and Lungka, P., "The development of teachers' knowledge and behaviour in promoting selfdiscipline: a study of early years teachers in Thailand," Education 3-13, vol. 47, no. 4, pp. 462-474, 2019.

[12] Prasertsang, P. and Nuangchalerm, P., "STEM education as a strategy for enhancing mathematical achievement on measurement," Journal of Education \& Social Policy, vol. 5, no. 1, pp. 130-134, 2018.

[13] Nuangchalerm, P., "Investigating views of STEM primary teachers on STEM education," Chemistry: Bulgarian Journal of Science Education, vol. 27, no. 2, pp. 208-217, 2018.

[14] Listiana, I., Abdurrahman, A., Suyatna, A. and Nuangchalerm, P., "The effect of Newtonian dynamics STEMintegrated learning strategy to increase scientific literacy of senior high school students," Jurnal Ilmiah Pendidikan Fisika Al-Biruni, vol. 8, no. 1, pp. 43-52, 2019.

[15] Prachagool, V., Nuangchalerm, P., Subramaniam, G. and Dostál, J., "Pedagogical decision making through the lens of teacher preparation program," Journal for the Education of Gifted Young Scientists, vol. 4, no. 1, pp. 41-52, 2016.

[16] Kinloch, V., Burkhard, T. and Graham, D., "Storying youth lives: Centering equity in teaching and teacher education," International Journal of Qualitative Studies in Education, vol. 33, no. 1, pp. 66-79, 2020.

[17] Tondeur, J., Scherer, R., Baran, E., Siddiq, F., Valtonen, T. and Sointu, E., "Teacher educators as gatekeepers: Preparing the next generation of teachers for technology integration in education," British Journal of Educational Technology, vol. 50, no. 3, pp. 1189-1209, 2019.

[18] Scaradozzi, D., Screpanti, L., Cesaretti, L., Storti, M. and Mazzieri, E., "Implementation and assessment methodologies of teachers' training courses for STEM activities," Technology, Knowledge and Learning, vol. 24, no. 2, pp. 247-268, 2019.

[19] Baran, E., Bilici, S.C., Mesutoglu, C. and Ocak, C., "Moving STEM beyond schools: sudents' perceptions about an out-of-school STEM education program," International Journal of Education in Mathematics Science and Technology, vol. 4, no. 1, pp. 9-19, 2016.

[20] Radloff, J. and Guzey, S., "Investigating preservice STEM teacher conceptions of STEM education," Journal of Science Education and Technology, vol. 25, no. 5, pp. 759-774, 2016.

[21] Erdogan, I. and Ciftci, A., "Investigating the views of pre-service science teachers on STEM education practices," International Journal of Environmental and Science Education, vol. 12, no. 5, pp. 1055-1065, 2017.

[22] Herro, D., Quigley, C. and Cian, H., "The challenges of STEAM instruction: Lessons from the field," Action in Teacher Education, vol. 41, no. 2, pp. 172-190, 2019.

[23] Chu, H. E., Son, Y. A., Koo, H. K., Martin, S. N. and Treagust, D. F., "The potential of arts-Integrated STEM approaches to promote students' science knowledge construction and a positive perception of science learning," In Hsu YS., Yeh YF. (eds), Asia-Pacific STEM Teaching Practices, Springer, Singapore, pp. 17-38, 2019.

[24] Najib, S. A. M., Mahat, H. and Baharudin, N. H., "The level of STEM knowledge, skills, and values among the students of bachelor's degree of education in geography," International Journal of Evaluation and Research in Education, vol. 9, no. 1, pp. 69-76, 2020.

[25] Hunter-Doniger, T., Howard, C., Harris, R. and Hall, C., "STEAM through culturally relevant teaching and storytelling," Art Education, vol. 71, no. 1, pp. 46-51, 2018.

[26] Clapp, E. P. and Jimenez, R. L., "Implementing STEAM in maker-centered learning," Psychology of Aesthetics, Creativity, and the Arts, vol. 10, no. 4, pp. 481-491, 2016.

[27] Nuangchalerm, P., Prachagool, V., El Islami, R.A.Z., and Abdurrahman, "Contribution of integrated learning through STEM education in ASEAN countries,” Jurnal Pendidikan Progresif, vol. 10, no. 1, pp. 11-21, 2020.

[28] Juhji, J. and Nuangchalerm, P., "Interaction between scientific attitudes and science process skills toward technological pedagogical content knowledge," Journal for the Education of Gifted Young Scientists, vol. 8, no. 1, pp. 1-16, 2020.

[29] Koh, J. H. L., "TPACK design scaffolds for supporting teacher pedagogical change," Educational Technology Research and Development, vol. 67, no. 3, pp. 577-595, 2019.

[30] Zhang, S., Liu, Q., and Cai, Z., "Exploring primary school teachers' technological pedagogical content knowledge (TPACK) in online collaborative discourse: An epistemic network analysis," British Journal of Educational Technology, vol. 50, no. 6, pp. 3437-3455, 2019. 